\title{
No More Than Human by Maura Laverty: Impressions of a Reluctant Governess in Spain
}

\author{
By Ute Anna Mittermaier \\ Trinity College, Dublin
}

Copyright (c) 2007 by Ute Anna Mittermaier. This text may be archived and redistributed both in electronic form and in hard copy, provided that the author and journal are properly cited and no fee is charged for access.

\begin{abstract}
This paper represents an imagological analysis of Maura Laverty's strongly autobiographical novel No More Than Human (1944) about the experiences of a young Irish governess in Spain in the 1920s. Drawing on the theory and methodology of imagology, it discusses the wellrounded image of Spain conveyed by Laverty's depiction of Spanish land- and cityscapes, characters, and socio-political conditions revealing the author's familiarity with widespread Spanish stereotypes. In line with the imagological tenet that the creation of hetero- and auto-images is interdependent, the paper shows how by having her heroine comment explicitly on Spanish society and politics of the 1920s Laverty indirectly expresses her attitude to her native country Ireland in the first decade of national independence. From both the political, religious, and moral values expressed in the novel under discussion and the scant existent biographical information on Laverty it is concluded that the writer shared the patriotism and the Catholic, rural, and patriarchal values of the official, Church- and State-sanctioned version of Irish nationalism. At the same time, however, she seems to have rejected the extreme moral conservatism propagated by statesmen and clerics in the early years of the Irish Free State.
\end{abstract}

Key Words. Maura Laverty, No More Than Human, imagology, national stereotypes, Ireland, Spain.

Resumen. Este artículo representa un análisis imagológico de la novela marcadamente autobiográfica No More than Human (1944) de Maura Laverty sobre las experiencias de una joven institutriz irlandesa en España en la tercera década del siglo veinte. Haciendo uso de la teoría y metodología imagológica, el artículo discute la compleja imagen de España creada por Laverty gracias a su descripción de las tierras, ciudades, personajes y condiciones socio-políticas españolas que revelan la familiaridad de la autora con la gran variedad de estereotipos de España. En línea con el principio de la corriente ideológica de que la creación de hetero- y auto-imágenes es interdependiente, el artículo muestra como por haber hecho su heroína comentarios explícitos sobre la sociedad y política española de los años veinte, Laverty indirectamente expresa su actitud hacia su país nativo Irlanda en la primera década de independencia nacional. En base a los valores tanto políticos, religiosos y morales expresados en la novela referenciada y la escasa información biográfica que existe de Laverty, se puede concluir que la escritora compartía el patriotismo y los valores católicos, rurales y patriarcales de la versión oficial del nacionalismo irlandés sancionado por la iglesia y el estado. Al mismo tiempo, sin embargo, ella parece haber rechazado el extremado conservadurismo moral propagado por políticos y clérigos en los primeros años del Irish Free State (Estado Libre Irlandés).

Palabras clave. Maura Laverty, No More Than Human, imagologia, estereotipos nacionales, Irlanda, España.

Maura Laverty's novel No More Than Human is reminiscent of her elder compatriot
Kate O’Brien's more widely read semiautobiographical romance Mary Lavelle insofar

ISSN 1699-311X 
as it similarly recounts the adventures of a young, inexperienced Irish governess in Spain in the 1920s. Like Kate O'Brien, ${ }^{1}$ Maura Laverty (1907-1956) could draw on personal experiences in her novel, for at the tender age of seventeen the writer had set out for Madrid to take up her post as a governess to a SpanishIrish family (Cf. Castle 1992: 6). Whereas O’Brien's Mary Lavelle as well as her other novels and non-fictional writings have been reprinted and rediscovered by critics since her death in 1974, Maura Laverty's oeuvre has almost sunk into complete oblivion. Although Laverty's first and third novels Never No More and No More Than Human were republished in the 1980s by Virago Press, Laverty's works have not received the same critical attention as O’Brien's writings in the past twenty years (cf. Clear 2001: 819). ${ }^{2}$ During her lifetime, however, Laverty was "one of post-war

1 O’Brien spent several months working as a governess for the wealthy and influential de Areavaga family in the Basque Country in 1922/3. Cf. Reynolds 1987: 36.

1 The scant bibliographical material on Maura Laverty the present writer was able to trace comprises: the notes on the author as well as Maeve Binchy's introductions in the Virago editions of Laverty's novels Never No More and No More Than Human; biographical sketches by Barry Castle (Laverty's daughter), Bonnie Kime Scott, Janet Madden-Simpson, Matthew Hoehn; entries on Laverty in biographical dictionaries: The Feminist Companion to Irish Literature in English, The Reader's Companion to Twentieth-Century Writers, Oxford Dictionary of National Biography, Women in World History. A Biographical Encyclopedia, Field Day Anthology of Irish Writing IV, The Oxford Companion to Irish Literature, A Biographical Dictionary of Irish Writers, The Encyclopaedia of Ireland, A Dictionary of Irish Biography; obituaries in Irish Independent, Irish Press, Irish Times, Dublin, 28-30 July 1966; comments on the popular Irish television series Tolka Row, based on Laverty's play Liffey Lane in Irish Television Drama: A Society and its Stories; reminiscences of Laverty in Bríd Mahon's memoir While Green Grass Grows (pp. 118-126) and in Fitz-Simon's The Boys: a Double Biography; Kate O'Brien's review of No More than Human for the Spectator; María Isabel Butler de Foley briefly discusses Laverty's No More than Human in her essay “ Each Other's Country: Some Twentieth Century Irish and Spanish Writers”; Yolanda
Ireland's most popular writers - the Maeve Binchy of the fifties" (Mahon 1998: 118). Her strongly autobiographical debut novel Never No More, in which she vividly describes the childhood experiences of Delia Scully in the Irish small town of Ballyderrig, the fictional equivalent of Laverty's home town Rathangan (cf. Kime Scott 1996: 683), was widely read and highly praised by Sean O'Faolain in 1942 in his preface to the novel (cf. O’Faolain 1985: vi). Moreover, by her premature death of a heart attack in 1966 she had achieved great popularity as a writer of plays (the Tolka Row trilogy and A Tree in the Crescent), cookery books, children's stories, an 'agony aunt' on an Irish radio station, and as the script-writer for the "highly successful television soap opera" Tolka Row (Parker 1995: 418).

The imbalance in the reception of Kate O’Brien and Maura Laverty can partly be explained by the fact that Laverty's straightforward and at times rather blunt style leaves less room for insightful critical interpretation than the more elegant prose and complex narrative structure characterising O'Brien's fiction. ${ }^{3}$ However, while the reader will find No More Than Human less satisfying in aesthetic terms than Mary Lavelle, Laverty's account of the experiences of a young 'Irish Miss' is no less interesting than O'Brien's version with regard to its representation of Spain.

This paper deals specifically with the image of Spain Maura Laverty conveys in No More Than Human. It draws on the theory and methodology of imagology, a specialist field of (comparative) literary studies dedicated to the analysis of representations of cultural alterity

\footnotetext{
${ }^{(\ldots 2)}$ González Molano dedicates two paragraphs in her thesis on Molly Keane and Kate O’Brien to Maura Laverty; the only academic essay focusing solely on Laverty's work has been published by Caitriona Clear in Women's Studies (see bibliography for full references).

${ }^{3}$ O’Brien's subtle narrative style manifests itself in Mary Lavelle, e.g. in her use of the bullfight to symbolise the impact of Spain on the eponymous heroine, of flashbacks to contrast Irish and Spanish settings, and of foil figures to set individual Irish characters off against Spanish protagonists
} 
in literature. ${ }^{4}$ While no specific universally accepted definition of the subject of imagology, i.e. the literary image of a foreign country, has been postulated, there is a consensus among imagologists that images are fictional constructs of the mind rather than truthful, objective representations of a country; they are generally conceived of as a conglomeration of different elements (directly or implicitly imparted statements about a country's landscapes, cities, people, traditions, politics etc.) with a complex structure (e.g. the tendency to contrast northern/western with southern/eastern countries). Rather than constituting invariable, fixed entities, images can alter along with changing socio-political conditions. However, certain elements tend to reappear in literary works of different historical periods and seem resistant to change. These "dominants" (Cf. Blaicher 1992: 6) are generally referred to as "stereotypes". They represent fixed, preconceived ideas about a country which claim collective validity and resist qualification even in the face of direct contact with members of that nation. National stereotypes occurring in literature do not necessarily reflect the writers' personal experiences in the country they are portraying

\footnotetext{
${ }^{4}$ Apart from images of foreign countries, literary representations of particular regions, ethnic groups, social classes or of any other community construed by the author as 'the Other' can form the subject of imagological analyses. For detailed discussions of the theory and methodology of imagology, see, e.g.: Leerssen, Joseph Th. 2000. "The Rhetoric of National Character: A ProgrammaticSurvey". Poetics Today 21/2, Summer. 267-292. Syndram, Karl Ulrich. 1991. "The Aesthetics of Alterity: Literature and the Imagological Approach”. National Identity: Symbol and Representation. J. Th. Leerssen and M. Spiering (eds.). Rodopi: Amsterdam.177-185; Firchow, Peter. 1990. "The Nature and Uses of Imagology." Toward a Theory of Comparative Literature. Selected Papers Presented in the Division of Theory of Literature of the Xith International Comparative Literature Congress (Paris, August 1985). Valdés, Mario J. (ed.). Peter Lang: New York. 135-142; Moura, Jean-Marc. 1992. "L’Imagologie Littéraire: Essai de mise au point historique et critique”. Révue de Littérature Comparée 3. 271-287. Pageaux, Daniel-Henri.1988. "Image/imaginaire", in Europa und das nationale Selbstverständnis. Imagologische probleme in Literatur, Kunst und Kultur des 19. Und 20. Jahrhunderts., ed. H. Dyserinck \& K.U. Syndram (Bonn): 367-380.
}

but tend to be taken over from previous literary representations of that country. ${ }^{5}$ The widespread use of the same stereotypes in the works of writers from different countries thus points to the intertextual component in the transmission of images.

While the semantic content of stereotypes can remain stable over centuries, the qualities expressed in them can be positively or negatively evaluated depending on whether the observed country is seen as friend or foe. Thus, imagological analyses of the representations of Spain have shown that from the $16^{\text {th }}$ to the second half of the $18^{\text {th }}$ century the French and English images of Spain were dominated by the so-called "leyenda negra" (black legend), i.e. the notion of the Spanish as an excessively proud, cruel, fanatically Catholic people recklessly exploiting their colonies and persecuting the adherents of other religions in the Inquisition. During the period of Enlightenment, Spain was further denounced by influential French intellectuals such as Voltaire and Montaigne as anti-European, backward, despotic, and priest-ridden, and the Spanish people were reproached for their passivity and idleness causing the country's political, economic, and cultural decline. Only towards the end of the $18^{\text {th }}$ century, when Spain had lost much of its previous political and economic power and no longer posed a real threat to the dominant European powers England and France, did the negative image of Spain change into a largely positive one in the writings of Romanticists. Interestingly, the idealised Romantic image of Spain continued to rely on the same old stereotypical ideas

\footnotetext{
${ }^{5}$ In their investigations of the genesis of particular images and stereotypes imagologists have shown that "our images of foreigners are not primarily formed by our experiences, our individual or collective contacts with foreigners and by the history of the political and social relations between two countries", but are most likely "derived from literary sources, ethnographic or historical studies, travelogues, novels and plays, and more recently also from films" (Stanzel, "National Stereotypes", 1). Individual fixed ideas about a nation often originated in the works of particularly influential writers such as Isidor, Montesquieu, and David Humes and were converted into long-last stereotypes by being copied and perpetuated by other writers. (Cf. Stanzel, "Zur literarischen Imagologie”, 12 ff. and "National Stereotypes, 2 ff.)
} 
of the Spanish as "proud", "idle”, "backward", "religious" etc.; the only difference was that those qualities were now positively evaluated as constituting the unique Spanish character and the Spaniards' love of their country and traditions (Cf. Guerrero 1992: 1632-5; Bodenmüller 2001: 397-418). ${ }^{6}$

It is against this theoretical and historical background that I will analyse Laverty's representation of Spain in No More Than Human in this paper. Adopting the broadly defined concept of the 'image' outlined above I will look closely at all aspects of Laverty's portrayal of Spain, i.e. the description of Spanish city- and landscapes, the characterisation of the Spanish people, and the depiction of socio-political conditions in Spain. In order to establish whether Laverty paints an imaginative, idiosyncratic picture of Spain or unquestioningly takes over stereotyped images of Spain - be it the powerful, 'proud' and 'cruel' Spain deriving from the infamous 'Black Legend' or the modern, touristy image of Spain as a perpetually hot and sunny country where the fiestas never end - I will discuss the writer's use or conscious avoidance of widespread Spanish stereotypes. On the basis of the analysis of the constituent elements of Laverty's portrayal of Spain I will finally draw conclusions as to whether the overall image of Spain conveyed in No More Than Human reflects the amicable historical relations between Ireland and Spain, its 'old ally' against 'perfidious Albion'?

\footnotetext{
${ }^{6}$ The changing images of Spain in European (above all French and British) literature have been discussed in numerous publications. See for example: García Cárcel, Ricardo. 1998. La Leyenda Negra. Madrid: Alianza; Pageaux, Daniel-Henri. 1992. "La péninsule ibérique et l'Europe: Ouvertures, fermetures, dérives". Komparatistik und Europaforschung. Perspektiven vergleichender Literatur- und Kulturwissenschaft. Ed. H. Dyserinck and K.U. Syndram. Bonn and Berlin: Bouvier. 253-264; López de Abiada, José Manuel y López Bernasocchi, Augusta (eds.). 2004. Imágenes de España en culturas y literaturas europeas (siglos XVI-XVII). Madrid: Verbum; Shaw, Patricia. 1997. "Sensual, solemn, sober, slow and secret: The English view of the Spaniard, 1590-1700". Beyond Pug's Tour: National and ethnic stereotyping in theory and literary practice. Ed. C.C. Barfoot, C.C. Amsterdam: Rodopi), 99-114.
}

Apart from assessing whether Laverty rather expresses hispanophilia or - phobia in the novel under discussion, I am particularly interested in establishing what kind of image Laverty creates of her own and her protagonist's home country Ireland. The interpretation of Laverty's representation of Ireland is informed by the imagological tenet that the creation of a hetero-image is usually

${ }^{7}$ Bowyer Bell points out that until the outbreak of the Spanish Civil War, the Irish, like the rest of Europe, took little interest in Spain's internal political affairs. Instead, "sentiment and tradition were the prevailing factors in Irish-Spanish relations” (Bowyer Bell 1969: 137) in the first decade following the establishment of the Irish Free State. The historical and cultural links between Ireland and Spain were manifold: according to an ancient legend, the Irish were descendants of the 'Milesians', the sons of the heroic Spanish king Míl Espáine, who invaded the Emerald isle around 2000 BC; the inhabitants of Spain's north-western province of Galicia claimed the Irish as their northern 'Celtic Brothers'; in the $16^{\text {th }}$ and $17^{\text {th }}$ centuries, the Irish and the Spanish repeatedly conspired against their common enemy, England. After the failure of all Irish-Spanish military interventions against England, thousands of Irish refugees (the 'Wild Geese') were integrated into the Spanish army and during the era of the Penal Laws Irish priests were trained in colleges in Spain and smuggled back into Ireland. Even though many Irish would have been unaware of the mythological, historical, political, and economic ties between their country and Spain, they were prone to feel a certain affinity for the Spanish people just for the fact that the Spaniards were a Catholic nation like the Irish and had had to defend their faith against foreign invaders in the past. For further information on historical relations between Ireland and Spain see the special edition on Irish-Spanish links of History Ireland, which contains the article: Carey, John. 2001. "Did the Irish Come from Spain? The Legend of the Milesians". History Ireland 9, Autumn. 8-11; Henchy, Monica. 1989. "The Irish Colleges in Spain”. Eire-Ireland, Spring. 11-27; Hillgarth, J. N. 1985. Visigothic Spain, Byzantium and the Irish. London: Variorum Reprints; Reynolds, Lorna. 1989. "Improbable Relations: Spain and Ireland". Krino 7. 54-66; O’Donoghue, Aingeal. 1992. "Ireland and Spain". Voices of Ireland-Veus D'Irlanda. Proceedings of the First Conference on Irish Studies. Eds. N. Bureu, P. Gallardo, and M. O’Neill. Lleida: Pagés Editors. 9-14; Sainero, Ramón. 1987. La Huella Celta en España e Irlanda. Torrejón de Ardoz: Ediciones Akal. 
paralleled by the conveyance of an auto-image, i.e. that while writers comment explicitly on social, cultural or political conditions in a foreign country, they tend to indirectly express their opinion on similar or different conditions in their home country. Thus, from expressions of admiration for or criticism of specific aspects of a foreign country's society, culture, politics etc. certain conclusions can be drawn about a writer's stance towards aesthetic, moral, and political values and attitudes prevailing in his/her native country. Consequently, my aim is to demonstrate that an imagological approach to Maura Laverty's No More Than Human taking both biographical facts and the novel's historical context into account can reveal a great deal about the author's attitude not only to Spain and the Spanish people, but also to her native country Ireland and Irish society. ${ }^{8}$

In order to explain the narrator's initial unenthusiastic response to Spain it is expedient to comment briefly on the 'governessing trade' between Ireland and Spain and on both Maura Laverty's and her heroine Delia Scully's motive for entering this business. By going to

8 It is important to note that my analysis of Laverty's hetero- and auto-images is not based on the assumption that the protagonist's comments on Spain represent the writer's personal attitudes. Even though the novel is strongly autobiographicalMaeve Binchy has pointed out that "those who knew her” (Binchy 1985: XV) confirmed that No More Than Human faithfully recounts Laverty's personal life-story - the extent to which Laverty's personal views of Spain equal or differ from her heroine's remains a subject of speculation given the scarcity of reliable biographical material on the author. Moreover, as the imagologist Karl U. Syndram has stressed, a writer's use of stereotypes does not mean that he/she believes in their validity. Rather, authors sometimes consciously deploy stereotypes for aesthetic purposes; e.g. they can use stereotypes to present characters as stock-figures, to satisfy reader's expectations, to conform to certain generic conventions, to provide comic relief etc. (Cf. Syndram, “The Aesthetics”, 186). However, the numerous choices underlying the representation of Spanish cities, landscapes, people etc. and their comparison with the Irish scene were made by the author and the image resulting from these choices is ultimately her creation. Therefore, it is possible to talk about 'Laverty's image of Spain' irrespective of whether Laverty's representation of Spain reflected her personal impressions of that country.
Spain to work as governesses the writer and her fictional alter ego "followed a course quite familiar to Irish girls of [their] age and background” (Binchy 1985: Xv). Irish governesses were in great demand in Spain in the 1920s, as many wealthy Spaniards wanted their children to learn English but were reluctant to hire English Protestant governesses. Most of the numerous Irish girls entering the 'governessing business' in Spain did so "because there were few other avenues" open to them (Binchy, 1986: vi). Lacking either the funds or the determination to complete some kind of professional training, there were few opportunities for them to make a living in Ireland other than in the domestic service or in agriculture. ${ }^{9}$ Being a maid or land labourer, however, seemed a less attractive idea than working as a governess in Spain. What drew Irish girls to Spain were "the noblesounding names, the hint of aristocracy in the employers, the mention of castle, stately home or at the very least huge residence”, the chance "to escape their mothers and their small towns", and the "hope of making a brilliant marriage” (Binchy, 1986: vi). ${ }^{10}$

${ }^{9}$ Clear points out that as late as in 1946 "about
three-fifths of Irish women who were 'gainfully
occupied', that is, recorded as employed, were
either domestic servants or assisting relatives in
agriculture; however, fewer than a third of all
females over 14 were gainfully occupied at all"
(Clear 2001: 821). 10 In narrating the experiences of young governesses abroad Maura Laverty and Kate O'Brien contributed to the popular 'governess genre' which had been established since the early $19^{\text {th }}$ century through the novels of such famous writers as their compatriot Maria Edgeworth (The Good French Governess), Anne Brontë (Agnes Grey), Charlotte Brontë (Jane Eyre, Villette), and (in the modernist period) Vita Sackville-West (Heritage). For detailed analyses of the 'governess genre' and/or further information on the governess's living and working conditions see e.g.: Anonymous. "Hints on the Modern Governess System." Fraser's Magazine 30 (Nov. 1844): 57183; Poovey, Mary. 1988. "The Anathematized Race: The Governess and Jane Eyre." Uneven Developments: The Ideological Work of Gender in Mid-Victorian England. Chicago: University of Chicago Press.126-63; Hughes, Kathryn. 1993. The Victorian Governess. London and Rio Grande: The Hambledon Press. I am indebted to Prof. María Losada Friend for these references. 
Maura Laverty's heroine Delia Scully seems to have been no exception. At the end of her debut novel Never No More the author has Delia, who reappears as protagonist in $N o$ More Than Human, explain to her beloved, recently deceased Gran why she accepted the post as a governess in Spain:

[Sister Liguori] asked me what I was going to do with myself now that you were ... you were ... now that I wasn't living in Ballyderrig any more. I told her the way things were, how Derrymore [i.e. the farm where Delia used to live with her Gran] had to be sold up to pay the bank and how I had no taste for the business in Kilkenny [i.e. her mother's dressmaking business]. And then she asked me if I'd like a job looking after three children in Spain. I thought it might be as well to make a clean break, Gran love, for since I can't be in Ballyderrig I might as well be in Australia. [...] And it won't be the same as if I were going to a real Spanish house. The children won't be real foreigners to me for Señora Basterra is a Wicklow girl herself and it seems she met her husband when she was a governess in Madrid." (Laverty 1985: 282/3). ${ }^{11}$

The passage shows that Delia leaves Ballyderrig reluctantly for the lack of other opportunities given that she cannot run her Gran's farm on her own but does not want to enter her mother's dressmaking business. ${ }^{12}$ If she cannot stay in her beloved Ballyderrig, she does not care where else she will live as she could never be as happy anywhere else in the world. She will not go to Spain because she is particularly interested in Spanish culture. Rather, the thought that she will not live in an entirely Spanish household as her future employer is an Irishwoman consoles her. Therefore, unlike O'Brien's heroine Mary Lavelle, Delia does not experience her exile in Spain as an excellent opportunity to escape

\footnotetext{
${ }^{11}$ Quotations from Laverty's No More Than Human are subsequently referred to as 'NM', followed by the pager number(s).

${ }^{12}$ Again, in No More Than Human, Delia explains to another Irish miss several weeks after her arrival in Madrid that she cannot go back to Ireland because "there's no way [she] could earn [her] living in Ireland for [she] wasted [her] chances at school [i.e. she dropped out of the teacher-training college]" (NM: 19).
}

from a stifling small town atmosphere. On the contrary, feeling lonely and homesick, Delia's thoughts again and again take her back to Ballyderrig so that the novel is interwoven with many funny anecdotes about people from her vibrant Irish hometown. Realising that Miss Carmody, a middle-aged Irish governess, could afford to live at home in Ireland if she wanted, Delia "wonder[s] that she should choose to stay in Spain" (NM: 13).

Delia's nostalgia for Ireland also expresses itself in her reaction to Spanish landscapes and scenes from everyday life. During her stay in the Basque Country, where her employers take her for the summer months, Delia finds it hard to concentrate fully on her job because the Basque scenery and the people remind her very much of Ireland and make her feel restless:

I liked watching the peasants who came in from the country to do their shopping in Las Arenas. In the appearance of these people the Indian-brown men in their grey smocks and red boinas, the sun-dried women in their cotton dresses and white rope-soled alpargatas, there was little enough to put me in mind of my own light-skinned heavy-suited friends who at that very moment were making ready to save the turf and earth the potatoes. Just the same, there was a similarity between them. It expressed itself in the peaceful easygoing walk. [...] The sight of the Basque peasants wakened little stirrings in me, and a hundred times a day I found myself thinking of how the gorse would be scattering its golden sovereigns at home, and how the banks along the Monasterevan road would be creamsplashed with primroses. (NM: 65)

The unsettling memories of home prompt her to write a pastoral, religious poem in which she describes three encounters with the Virgin Mary in the Irish countryside in spring, summer, and winter. By contrast, she finds little beauty in the very different austere landscape and the high blue skies of Castile, which in her opinion compare unfavourably with the green hills and white skies of Ireland and the Basque Country. This already expresses itself in her remark that Juanita, the skinny Castilian cook of Delia's Spanish employers, "looked exactly what the unmotherly arid soil of Castile would produce, a stunted hardy olive-tree of a woman" (NM: 34). Again, during a motorbike-ride through "the arid Castilian acres", she "[has] a great longing to rest [her] eyes on the rich freshness 
of an Irish wheatfield", for "[b]rilliance of sun and sky and overcoloured landscape are little addition to someone who is hungering for the gentle shading of the bog” (NM: 211). Her nostalgia for Irish wheatfields inspires her to write another religious poem in which she praises the holiness of wheat from which the Body of Christ is made.

Delia's unpleasant experiences with her employers do not really endear Spain to her either. Señora Basterra, who had been the Irish governess Peggy Kelly from County Wicklow before marrying a wealthy Spanish businessman, turns out as a "stand-offish" (NM: 8), prudish snob. In the service of the Marquesa de las Rojas, however, she feels even more imprisoned than before. Being forbidden to dress up, to date men, and to smoke, she concludes in dismay that "a governess may eat, sleep and breathe and go sedately about her lawful occasions but she must give no other evidence of being a normal living creature" (NM: 75). Such an "atmosphere of chilling propriety" runs counter to her romantic preconceptions of Spain:

I had visualized Spain as a laughing bareshouldered girl with a rose in her hair. She had turned out to be a bleak-eyed forbidding wardress, with a bunch of keys in one hand, a penal code in the other. (NM: 75) ${ }^{13}$

Unable to procure another position as a governess to another Spanish family after having scandalised the Marquesa by playing beach ball with a Scottish boy dressed in a scarlet swimsuit, Delia is forced to eke out a living by hiring herself out as a private English tutor. For several months she barely earns enough to keep herself alive. Strolling through the dodgy quarters of Madrid, she is horrified by the poverty and squalor she witnesses. The sight of countless maimed beggars in the streets is completely new to her: "How was I to know that a world which held the loveliness of Ballyderrig, held too these frightening awful miseries?” (NM: 26). Prostitution is another novelty to her and so she is deeply shocked when she observes an evil-looking old procuress in a café trying to draw men's attention to a heavily made-up timid girl.

${ }^{13}$ This is only one of several instances in which Delia displays her awareness that stereotyped images of Spain rarely stand the test of reality.
Her anonymous, isolated life in Madrid, where she must fend for herself for the first time in her life, differs starkly from her sheltered existence in Ballyderrig, her beloved hometown vividly depicted in Never no More, where all people knew each other and helped each other out in difficult situations. Being naïve and unprepared for the dangers which life in a big city holds for a young, unattached girl, she is prone to be taken advantage of by the many sinister characters she encounters in Madrid. Thus, her mostly negative experiences with men in Spain seem to confirm the stereotype that Spaniards are notorious womanisers. Walking through both the elegant and the more sordid streets, she soon gets the impression that Spanish men of all social backgrounds are conditioned to whistle after any woman that passes them by (Cf. NM: 25). While she is "grateful" (NM: 25) for the workmen's compliments, the hungry glances of the well-dressed gentlemen "who sauntered speculatively through the Retiro or along the Castellana” (NM: 25) make her feel cheap. She also observes that Spanish husbands tend to stray away from their wives. Juanita, the Basterras' cook, has hated all men since her husband left her for a rich widow. Her aptly named employer Don Juan spends most of the nights with his mistresses. While Delia feels safe from any sexual advances by the fathers of her charges "due to the Spaniard's regard for $e l$ hogar, the home" (NM: 78), Don Juan's conceited nephew Eugenio seizes every opportunity "of honouring [her] with his treacle-dripping glances and a selection from the handbook on How to Win Hearts and Influence Women which seems to be issued to Spanish boys with the Ha'penny Catechism" (NM: 160). He stalks her and insults her by secretly reading and misinterpreting a perfectly innocent letter from her friend Luis. The man who hurts Delia most deeply, however, is Rafael, a young Spaniard with whom she goes out for eight weeks, believing that he has serious intentions of marrying her. When dining out one night Rafael rushes her out of the restaurant after he has spotted his mother, sister, and uncle at another table. He then explains to her that he cannot introduce her to his family as "a matter of etiquette" (NM: 152) for he is supposed to marry his cousin. "But", he adds, "it need make no difference to us. We could have the little house just the same" (NM: 
153). These words cure Delia of her folly. In retrospect, the mature Delia narrating her adventures in Spain realises without bitterness that while saying goodbye to Rafael, she "had grown up" (NM: 153). Thus, an unhappy love affair in Spain provides the catalyst for the maturation of Laverty's heroine.

Despite all the misfortune the young Delia suffered in Spain, her older self does not remember her lengthy stay in that country as a complete nightmare. Unlike many other Irish governesses, "who became beached and bitter" and "passed their time in continuous condemnation of the country where they had chosen to live” (Binchy 1986: vi), Delia lives life to the full in Spain. She teaches herself to type and do shorthand, and, like Maura Laverty herself, finally lands a job in an Irish bank and later writes for a Spanish newspaper. ${ }^{14}$ However, it is mainly thanks to the extreme kindness of several Spaniards that she manages to keep her homesickness in check and lives to see many happy days in Spain. Her gregarious nature and her ability to pick up Spanish quickly make it easy for her to become acquainted with Spaniards of different social backgrounds. Thus, she finds a 'substitute Gran' in La Serena, the saintly, hard-working servant in a boarding house. The memory of that generous old woman fills Delia with sentiment: "I loved La Serena from the minute I laid eyes on her. [...] [She] was the most gentle, most humble soul I have ever known" (NM: 98). But Delia also has fond memories of Luis Sotelo, a hospitable, intellectual theosophist, who invites her to dinner parties and picnics with his Spanish friends, procures her a job as English tutor to his friend's daughter, and widens her intellectual horizon by discussing both Spanish and Irish literature with her:

There was no end to his kindness. [...] He was the makings of a saint, and one had only to look at him to know it. The gentle mouth, the nice open forehead and the good eyes: these said, "Here is a man who is all virtue" (NM: 109).

Finally, Delia is also full of praise for 'Mamá Antonia' and 'Papá Antonio', the

\footnotetext{
${ }^{14}$ The newspaper Maura Laverty herself wrote for in the 1920s was El Debate (cf. Kime Scott 1996: 684).
}

Catalan cake-shop owners who let Delia stay in their house in return for her English lessons to their son and offer to employ La Serena as their maid after she has been dismissed by the mean landlady Doña Luz. This family "will always stand for the real Spain with [her], the warm-hearted innocent lovable Spain that I found best worth knowing” (NM: 188). Indeed, it is the merit of these good-natured people that Delia finally finds a second home in Spain, albeit it can never fully replace her beloved Ballyderrig.

Laverty's portrayal of a number of extremely kind Spaniards is on the whole balanced in that it encompasses both kind, generous, honest and treacherous, mean, hypocritical characters. At the same time, however, it is fairly simplistic and reductionist as it relies heavily on generalisations. Thus, Laverty has her protagonist establish that "[t]here is nothing diluted about Spaniards. They are either one thing or the other. When a Spaniard is kind, his heart is as big as a clamp of turf” (NM: 196). Consequently, if individual Spaniards strike Delia as evil, they are evil through and through and their bad nature shows in their appearance. For example, the looks of Doña Luz, the mean, slatternly landlady of a run-down boarding-house who treats La Serena like a slave, are described in very unflattering terms:

She wore a dirty dress of flowered black print [...]. Her coarse greying hair was cropped untidily. [...] Her skin was thick and greasy. She had a broad nose pinpricked with pores, and a mouth that was thin and twisted and colourless like an old scar. The eyes, though dull, were knowing. They were all pupil, with no whites at all to be seen. The stains under them were of so deep a brown that it seemed as if the woman had cried once and that the colour in her eyes had run a little. (NM: 179)

In her depiction of Spaniards Laverty also draws frequently on stereotypes, as, for example, when she has her protagonist say about an Aragonese fellow-lodger in a Madrid boarding house: "I had heard that the people of Aragon were the Scots of Spain. They had a great name for thrift. Rico bore this out” (NM: 114). Similarly, Flora, the Andalusian kitchen maid at the Basterras', is described as "full of southern languor and ease" (NM: 32), while Mamá and Papá Antonio are admired for their "hardworking Catalan way” (NM: 188). On 
other occasions, however, she shows her awareness that stereotypes do not always apply. For example, recalling how her friend Luis's sister Romana gave vent to her jealousy by warning her not to hurt her friend again or she will regret it, she adds: "[t]hat was the only glimpse I had in Spain of the stiletto-in-thestocking woman of the novelists" (NM: 191). ${ }^{15}$

Moreover, Laverty's depiction of Spanish characters is marked by a clear distinction between upper and working class Spaniards. Delia's comment "I have always been attracted to people who have known hardship" (NM: 103) goes a long way toward explaining why Delia reserves all her sympathy and admiration for poor and/or hardworking Spaniards like Juanita the cook, La Serena, and Mamá and Papá Antonio. As Clear has pointed out with reference to characterisation in Laverty's writings in general, "[m]oral worth derives from competence and generosity" (Clear 2001: 827). Consequently, skilled and diligent workers, cooks, and housewives like Rosaria, who helps Delia to make a dress and proves to be an excellent needlewoman, are even forgiven for cheating on their husbands. By contrast, Delia has no kind words for wealthy, powerful, and idle upper-class Spaniards. Her second employer, the Marquesa de Las Rojas, is described as "cold", "contemptuous", "untouchable" (NM: 56), while her next dueña Doña Conchita turns out to be "a nag and a belittling bully” (NM: 158). Doña Conchita’s

\footnotetext{
${ }^{15}$ In this particular instance the narrator displays her familiarity with the widespread stereotypical idea of Spanish women as violently jealous, vengeful, impetuous, and sultry. The idea of Spanish women carrying a stiletto in the stocking which Delia has repeatedly come across in fiction obviously derives from the eponymous tragic heroine of Bizet's famous opera 'Carmen'. The impact which 'Carmen' has had on the formation of a certain image of Spanish women circulating outside Spain is not a unique phenomenon. As Michael Barke has observed, like Carmen, Cervantes's Don Quixote have come to be seen as "a real person" by many readers and "the figures of Don Quixote and Sancho Panza have attained a life of their own quite independent of the book" (Cf. Barke 1999: 87-8). These two examples of famous literary/operatic figures whose qualities have come to be widely associated with the Spanish people in general, confirm the imagological tenet that literature plays a seminal role in the creation and dissemination of national images.
}

husband is a "cold stern little man" with a "big-business-man strut" displaying his "moneyed cocksureness" (NM: 158). The Señoras' excessive concern about their employees' correct manners and morals appears ironic and hypocritical given that it is widely known that their own husbands cheat on them.

Laverty's unsympathetic portrayal of the Spanish aristocracy and bourgeoisie reflects her heroine's dismay at the extreme social injustice she witnesses in Madrid. Spain in the 1920s was a deeply divided class society with the vast majority of land and capital being owned by a small percentage of extremely wealthy aristocrats and industrialists, while the majority of the Spanish people employed in agriculture or industry lived in poverty (cf. Garrioch 1993: 6-8). The country had been divided into two major camps, "the forces of new Spain -republicanism, socialism, democracy- and old Spain (the army, the Catholic Church, monarchists and wealthy elite)" (MacGarry 1999: 14) since the early nineteenth century (cf. Beevor 1982: 14-16, Preston 1996: 10-11). Although the tensions between these 'two Spains' -each of which constituted a heterogeneous mix of adherents to different rightist/leftist ideologies rather than a unified block- did not erupt into a bloody civil war until 1936, they were already palpable in the preceding decade, when Spain was governed by the dictator Primo de Rivera (cf. Preston 1996: 20-23, Carr 1980: 98-116). Although Spanish politics proper do not feature prominently in Delia's tale, ${ }^{16}$ Laverty

\footnotetext{
${ }^{16}$ Even though Delia gets into contact with politically active Spaniards such as the anarchist Juan Negrin and one of her employers, a close friend of "Gil Robles whose articles in El Debate were even then making a stir" (NM: 94), she admits that "[she] was too young and ignorant to be interested" (NM: 94). The adult narrator, "thinking back over her time in the newspaper [i.e. her work for a conservative Spanish daily] ... regret[s] that [she] did not take an intellectual interest in what was happening around [her]” (NM: 218) and that although "[t]he design Spain took in after years was shaped in that newspaper and ... [she] was in the very middle of it, [she] noticed nothing” (NM: 218). However, she refrains from elaborating on the nature of the "design" Spain would later take. The Spanish Civil War and the subsequent establishment of Franco's dictatorship in Spain are not mentioned in the novel.
} 
has her heroine demonstrate an awareness of the revolutionary climate prevailing in Madrid in the 1920s in a series of brief imagined episodes in which representatives of the 'old, traditional Spain' including King Alfonso, Primo de Rivera, and the Jesuit editor of El Debate try to reassure themselves that the traditional social and political order in Spain remains unchallenged, while "under the crust of custom there was a yeasting and a bubbling of change" (NM: 134). Moreover, the narrator expresses her frustration about the profound socio-economic inequalities in Spain not only indirectly in her scathing remarks on upperclass Spaniards. Thus, after hearing that the Andalusian peasants only earned "two pesetas a day", while her employer "spen[t] twentyfive pesetas every day of his life on cigars alone” (NM: 123), Delia admits that she agrees with the "anarco-sindicalista" (NM: 112) and revolutionary cartoonist Juan Negrin when he criticises the Spanish priests for their lack of solidarity with the poor (Cf. NM: 124).

All in all, the image of Spain Laverty conveys through her descriptions of Spanish land- and cityscapes, Spanish characters, and the socio-political conditions prevailing in Spain in the 1920s is quite ambiguous. On the one hand, her heroine is appalled by the clash of extreme poverty and outrageous affluence in Madrid, feels alienated by the barren landscape of Castile and obviously enjoys her stay in the Basque Country mainly because the Basque scenery strongly resembles that of her native Emerald Isle. Her numerous negative experiences with Spanish men seem to bear out the stereotype that all Spaniards are Don Juanesque heartbreakers. Besides, her employers' strict rules of conduct lead Delia to liken Spain to "a forbidding wardress" and the failure of one of her students to offer her a share of her sumptuous meal prompts her to complain: "in any case, hospitality is not one of the Spanish virtues. With all due respect to Spain I felt Ireland could teach them something there" (NM: 96). On the other hand, the generosity of her boss at a Spanish office, who raises her salary while she is recovering from scarlet fever, incites Delia to comment "I would be ungrateful if I did not say that this good nature was typical of every office in which I worked in Spain" (NM: 230). Similarly, apart from lady-killers, Delia meets thoroughly virtuous Spanish gentlemen like
Luis Sotelo, who has lost all interest in the pursuit of women since the death of his beloved wife, and his friend Juan Negrin, who is utterly devoted to his dying wife.

The many contradictions in Laverty's representation of Spain result to a great extent from the fact that Delia's fortunes change significantly for the better in the course of her stay in Spain. At the beginning she is 'a reluctant governess in Spain' given that, homesick, lonely, and grief-stricken over the death of her grandmother, she is unable to regard her stay in Spain as anything else but an involuntary exile and soon discovers that her vivacious character is ill suited to the constrained lifestyle of a governess. From the moment she quits governessing, takes up residence in public boarding houses, and earns her own living as a private English tutor, however, she is fully drawn into Spanish life and, in her encounters with Spaniards from all different walks of life, she matures from a naïve, inexperienced girl into an independent, self-confident woman. It is thanks to this positive turn of fate that the adult narrator recounting the experiences of her younger alter ego is able say that the Spanish people are as "spicy and fragrant and exciting and warm" (NM: 36) as their food and that Tomasina the wet-nurse "embod[ies] [Spain's] generosity, its warm-heartedness, its kindness to children, its decent good-living common people, its saints, its painters and its poets" (NM: 63). These complimentary remarks on the Spanish people in general suggest that the mature Delia's positive memories of Spain outweigh the negative ones. At the same time, the circumstance that the narrator's general assessments of the Spanish character are repeatedly refuted by her personal experiences with individual Spaniards confirms what imagologists have endeavoured to prove since Dyserinck outlined the theoretical and methodological tenets of imagology in the 1960s, namely that the idea of the existence of a uniform 'national character' is a myth (Cf. Dyserinck 1966: 1-7-120, Leerssen: 128, Syndram: 183). As in any other nation, the good and the bad, the generous and the mean also exist side by side in Spain and all stereotypes and other generalisations about Spain and its inhabitants inevitably fail to capture the enormous complexity of such a vast country. In this light, Laverty's creation of 
a quite ambiguous overall image of Spain can be seen as an achievement rather than an artistic flaw given that it reflects the writer's endeavour to do justice to this complex reality.

In order to ascertain whether Laverty expresses a similarly ambiguous attitude to Irish society, politics, and culture in her indirectly conveyed auto-image, it is indispensable to take the novel's historical context, i.e. the socio-political conditions prevailing in Ireland in the 1920s -the time of the novel's setting- into consideration. In the 1920s/30s the Irish Free State was still a fledgling democracy whose inhabitants were troubled by doubts about the viability of an independent Ireland divided from its industrialised northern province and by a rather vague notion of what it meant to be Irish. In order to instil national pride and a sense of togetherness into the Irish people, the architects of the Irish Free State -mostly adherents of cultural nationalist movements such as Irish Ireland, the Gaelic League, and the Celtic Revival as well as leading members of the Irish Catholic Hierarchy- propagated an Irish auto-image which was based on the definition of Irishness in opposition to Englishness. Given that English society was seen as modern, urban, liberal in moral/sexual issues, materialistic, imperialist, Protestant and atheistic, the Irish were encouraged to conceive of themselves as a conservative, rural, patriarchal, anti-materialistic, self-sufficient, and fervently Catholic people (cf. Brown 1991: 89-92 and Part I:1922-32 in Brown 2004). The "post-revolutionary quest for national selfdefinition" moreover led the ideological architects of the Irish Free State, i.e. the politicians and the Catholic hierarchy, to propagate a conservative-puritanical attitude to sexuality which "equated sex with procreation rather than passion, and sanctioned it only within marriage” (Howes 2002: 923). While "sexual immorality" was "often cast ... as English or, more generally, foreign”, "sexual purity" was claimed "as naturally and genuinely Irish” (ibid.: 925).

Reading No More Than Human with a particular focus on the narrator's expression of religious, political, social, and moral-sexual, values in her comments on Spain as well as in her descriptions of Irish landscapes and people yields interesting insights into Delia's attitude to the conservative official nationalist and strongly Catholic-influenced ideology still prevailing in Ireland in the 1940s, when the novel was written. As will be demonstrated below, some of Delia's remarks reveal political-religious views suggesting her subscription to the Catholic, rural, patriotic/anti-English values propagated by conservative Irish nationalists. Thus, her strong devotion to Catholicism manifests itself in her poems praising the Virgin Mary and the sanctity of the Host (Cf. NM: 66, 211/2) as well as in her conviction that "God is nearer than the door" (Cf. 165, 178), i.e. that God will always help her out of trouble by opening a new door when another one has been shut. Similarly, Delia's Catholic faith prevents her from relating fully to her short-term fiancé, the Hungarian business agent Siemen Kronz. Recalling her first encounter with Siemen Delia admits that, despite his good looks "[she] did not take to him. His foreignness disconcerted [her]" (NM: 121) and adds that

Spanish people had never had this effect on me. I had always felt a kinship with them. We differed in speech, looks and habits, but these differences went no deeper than the varicoloured dyes which are used to the shells of eggs at Easter time. Siemen's foreignness went right to the speck of the egg. (NM: 121)

Although she does not explicitly say it, the Hungarian seems more foreign to her than the Spanish people because he is not Catholic. The fact that he is "a Lutheran" (NM: 201) seems to be one of the main reasons for her reservations about getting married to Siemen. His irreverent way of talking about Spanish religious festivals, for example, "[makes her] feel uncomfortable” (NM: 201) and incites her to drag him into a Catholic church and sprinkle holy water on him.

Whereas their Catholic religion enables her to relate easily to the Spanish people in general, the special affinity she feels for the Catalans seems to have political reasons:

I learned that there was a close kinship between the Catalonians [sic] and the Irish. Their long fight for independence, their yearning for individualism as expressed in the way they clung to their language and customs, and their love of liberty as shown in their demand for republican status - all these things made a brother-bond for us. (NM: 189) ${ }^{17}$ 
Delia's nationalist sentiments further manifest themselves in the numerous instances in which she insists on her Irish identity or stands up for her country against ignorant foreigners. For example, she finds it ridiculous that Señora Basterra, in her effort to conceal her modest Irish origins, "discarded her Irish accent and had cultivated the way of speaking of the English colony" (NM: 9). Although she does not immediately correct Rafael when he takes her for an English girl as she is "becoming accustomed to the Spaniards' way of robbing the Irish of their nationality", she feels that he has "denuded [her] of [her] ancestry of saints and scholars" (NM: 48). Similarly, being desperate for money, she only answers a potential employer's question whether she is English in the affirmative "with a mental apology to Ireland's dead" (NM: 157). She even loses a job in a language school over a fight with her French boss who asks her "if it was true that the Irish kept pigs under their beds" (NM: 91).

Arrogance and ignorance about Ireland and other countries, however, are more frequently associated with the English. Thus, Delia's observation that the English lads she meets in Bilbao "[are] full of lordly condescension" and "[have] the greatest contempt for Spanish boys of their own class", makes her hypothesize that

the colonizing tradition may have something to do with this little peculiarity on the part of the British. It does something to their brain, making them imagine every foreign country is Darkest Africa and that all foreigners are bushmen. (NM: 87)

In voicing her anger at the English boys' habit of referring to the Spaniards as 'dirty

17 Catalonia, like Ireland, had experienced a rise in nationalist consciousness since the late $19^{\text {th }}$ century. Feeling that they themselves were no less colonised, suppressed, and economically exploited by a foreign power - in their case Castilian-dominated Spain - than the Irish, the Catalan nationalists took great interest in the protracted Irish struggle against British rule and emulated their Irish counterparts. Thus, in Valencia a political party called Joventut Obrera Nationalista (Nationalist Labour Youth) was established, "which drew explicitly on the Irish nationalist experience” (Boada-Montagut 2002: 2). Besides, in the 1930s several political activists fled from Catalonia to Ireland, from where they published nationalist pamphlets.Cf. Boada-Montagut 2002: 2-22. dagoes” (NM: 86) and relating it to a general tendency among the British to consider themselves superior to all other nations, Delia displays a strong sense of solidarity with the Spanish people which can be ascribed to her familiarity with British misrepresentations of her native country Ireland. As Alan Titley has pointed out, the Irish "have had a fairly bad press for the best part of two thousand years" (Titley, quoted in Zach 1987: X) owing to the largely negative image of Ireland created by British writers which "served the British colonizers as a handy argument to justify all their measures to crush Irish resistance against colonial rule since the Middle Ages" (Zach, XI). Still, Delia cannot really be accused of absolute Anglophobia. After all, she concedes that the widespread negative Irish image of the "Typical Englishman" combining the worst character traits and "all the ill-favoured, ungainly odious physical attributes that have ever hurt the human eye" (NM: 101) is an artificial construct which serves just as well as an apt description of certain unpleasant characters "who were bred and born in Ireland" (NM: 101). Moreover, she befriends the English secretary Miss Wilson, who offers to lend Delia her textbooks on typing and shorthand - an offer which in Delia's opinion "wiped out Ireland's grudge against England" (NM: 106).

Whether Maura Laverty herself shared her heroine's nationalist sentiments cannot be established with absolute certainty. The humorous tone of the narrative makes most of Delia's patriotic comments sound slightly ironic. However, in the light of some of the aspects of her representation of Spain and Ireland pointed out above, it seems rather unlikely that Laverty satirised Irish nationalism in her novels. By idealising life in the Irish countryside in Never No More and in Delia's reminiscences of her hometown in No More Than Human, by contrasting it with the moral pitfalls of city-life, and by having her heroine express both her love for her country and her strong Catholic faith in religious poems the author demonstrates that she shares some basic values with Irish (cultural) nationalists. Moreover,

the importance that Laverty's writings give to cooking and home-making18could be taken to suggest that she agreed with those [Irish nationalist politicians and clergymen], who 
believed that Irish women should stay quietly and uncomplainingly in the home. (Clear 2001: 822)

Indeed, while Laverty was one of the first Irish women to earn a living by writing and to become actively involved in Irish politics, she does not convey any feminist messages in No More Than Human. Rather than making her heroine celebrate her independence as a wageearning woman, she first has her get engaged with a Hungarian whom she does not really love and then has her return to Ireland and marry an Irishman. Finally, Laverty's conservative-nationalist attitude also manifests itself in her membership of the national executive of Clann na Poblachta, the shortlived political party whose cultural programme included plans

to remedy the 'alien, artificial and unchristian concepts of life' which were 'being constantly pumped into and absorbed by [the Irish] people' $[. .$.$] to create a national theatre and$ film industry; to produce films and books for educational purposes and for making Irish the spoken language of the people; to safeguard and extend the Gaeltacht areas [...] (Keogh 1994: 192).

Whereas a close analysis of No More Than Human draws attention to aspects of a conformist, nationalist ideology underlying the text, Laverty's novel can certainly not be read as a paradigm of Catholic-nationalist propaganda. In fact, since the novel was banned it was obviously not considered as recommendable, edifying reading for the Irish people. Given the absence of any subversive political comments in the novel, the representatives of the Irish Censorship Board must have found it wanting in moral respects. ${ }^{19}$

18 In her analysis of Laverty's works Caitriona Clear points out that motherhood, food, and housekeeping are important themes in all of Laverty's writings and that sympathetic female characters are usually also loving mothers and competent cooks and housewives. Thus, in No More Than Human, the Basterras' cook Juanita, La Serena, and Mamá Antonia are admired by Delia for their motherly qualities as well as for their excellent cooking and housekeeping skills.

${ }^{19}$ Given that the Censorship Board, made up of five members appointed by the minister for justice was and still "is not required to give detailed explanations of why publications are banned"
Presumably they took issue with the narrator's frank way of expressing the celibate Irish misses' sexual curiosity ${ }^{20}$ as well as with her refusal to stick to her employers' strict rules of conduct and her humanistic, liberal views on such matters as prostitution. ${ }^{21}$ Delia's sympathy for people whose 'immoral' actions are motivated by extreme poverty or foolish love and her scorn of the excessive prudishness of some of the Irish governesses as well as of her Hungarian fiancé ${ }^{22}$ must have fallen foul of the censors' moral standards. Clear points out that in 1949 the ban was lifted on an altered edition of the novel and observes that the chapter that was changed most radically is the one featuring Tomasina, the wet nurse, who was

(...19) (Carlson 1999: 105), the exact reasons for banning No More Than Human are unknown. As Carlson points out, "[u]nder the 1929 Act books are banned indefinitely either because they are 'indecent or obscene' or because they advocate 'the unnatural prevention of conception or the procurement of abortion or miscarriage” (ibid.). Laverty's book might have been banned both because it was deemed 'indecent' on account of its explicit references to prostitutes, exposed breasts, sexual curiosity etc. and because it contains a scene in which La Serena secretly carries out an abortion (cf. NM: 130)

20 The censors were probably scandalised at statements like "We [Irish misses] were all extremely vague about the realities of sex. [...] We retained our Victorian idea of the marriage bed as a place where men might love but women must weep. [...] We were devoured with curiosity as to What Actually Happened" (NM, 84), and "When Siemen and I were not making love we were quarrelling" (NM, 214).

21 Cf. NM: 96, Having experienced extreme hardship herself, Delia comes to understand how hunger can drive women into prostitution. The first time she comes face to face with "women of that class" (NM: 45) she finds that there "was nothing in their appearance to inspire the scandalized horror which, as a well-brought-up girl, I knew I should be feeling. Instead that little line jumped into my head '... for the good are always the merry....' If that was true, there was far more goodness at that table than at ours" (NM: 45).

22 Siemen pre-empts the censors' job when he judges the line in Delia's love poem - "[I] Carry my breasts with royal thrusting lift" - as "rather coarse" and replaces it with "Carry my head with proud and royal lift” (NM: 216). 
"voluptuousness incarnate" (NM: 61). In the original version Tomasina entertains the older children of the Marquesa de las Rojas "by squeezing one of those great inexhaustible breasts and squirting a jet of milk across the room" (NM: 72). When the children's puritanical Irish governess Miss Madden reprimands her for her disgraceful behaviour, Tomasina splashes milk on the miss's blouse. In the altered edition, all the wet nurse does to scandalise Miss Madden, is to breastfeed the baby before the eyes of the children and to hiss "Mierda" at her. As Clair comments, "[o]bviously mierda was considered a more acceptable bodily substance for Irish readers [than mother's milk]" (Clear 2001: 826).

On the whole, more than anything else, No More Than Human is a highly entertaining, strongly autobiographical novel narrating the coming-of-age of a young Irishwoman in Spain. Laverty's narration is fairly straightforward and lacks the complexity and symbolism of Kate O’Brien's Mary Lavelle. In her review of No More than Human for the Spectator, Kate O’Brien actually criticised the loose structure of the novel as well as Laverty's failure to distance herself sufficiently from her protagonist:

Miss Laverty has a vivid, amusing and true story to tell; and she tells it with verve and wit, decorates it with rich detail of everyday life in Madrid and in provincial Spain. But she has not given her tale the deep perspective which the novelist must give; she still stands too near to her central figure; she remembers still rather than imagines. [...] In short, the whole thing is rough, jolly and loosely confidential, it is good and sincere, but it has not been composed into a fable, into a novel.

(The Spectator, 22 Dec. 1944, 584).

Nevertheless, O'Brien applauded the sincerity of Laverty's representation of Spain which set it positively apart from the multitude of faulty, biased, and/or romanticising literary portraits of the country in circulation in the 1940s:

[L]eaving that technical failure aside, [...] it is meanwhile very satisfactory to read some plain truths about everyday life in Spain, and to find a Catholic writer speaking out with courage and good sense, without fear or favour, on Spain's internal difficulties. [...] here is someone who knows the Spain of which she writes. That is something one cannot say of many foreign novelists who write about Spain (ibid.)

Indeed, while the positive development of the protagonist's fortunes in Spain enables her to remember her stay in that country as a largely positive, enriching experience, Laverty succeeds in crafting a well-rounded image of Spain by tempering lush landscapes with arid ones and good personalities with bad ones, by alternately confirming and contradicting national stereotypes, and by having her protagonist both criticise the unjust nature of Spain's class-ridden society of the 1920 s and express her feeling of a strong affinity for the Spanish people in general.

By contrast, the image which Laverty imparts of Ireland in the novel seems far more straightforwardly positive even though, as has been shown above, it simultaneously brings out Laverty's conflicted, ambiguous attitude to Irish nationalism. The narrator's frequent flash-backs to her happy childhood in her Irish hometown and her direct comparisons between Irish and Spanish landscapes and people leave no doubt that she values Ireland over Spain. Furthermore, there is nothing to suggest that by representing the social ills and male domination in Spain the author indirectly criticises similar conditions in Ireland. On the contrary, life in rural Ireland, where there is "only one class" (NM: 215), is idealistically depicted as vibrant, idyllic, and definitely preferable to the anonymous, dangerous life in a big, socially divided city like Madrid. Despite having to leave her beloved native town for the lack of job opportunities, Delia never blames the patriarchal structure of Irish politics and society for blocking women's careers. Nor does she question the 'natural' role of women as mothers and housewives. Instead of encouraging her female readers to follow her example of getting a job abroad she completes her story with a 'happy end' by returning to Ireland and marrying a decent Irish farmer. The conformism of Delia's creator further expresses itself in her heroine's religious poems illustrating her Catholic piety and her national pride. On the other hand, Laverty's portrayal of Delia as a sexually curious rebel against conservative rules of conduct for girls and her frank descriptions of female body parts (cf. Tomasina's "inexhaustible breasts", NM: 87) and of breastfeeding as a sensual experience suggests 
that she did not approve of the misogynistic, Jansenistic moralism of (male) nationalists and clergymen defining women as passive, asexual beings. Therefore, one can conclude from the political and moral values expressed in Laverty's fictional representation of her experiences in Spain that while she embraced the patriotism and the rural, religious, and patriarchal values of official, Church- and State-sanctioned Irish nation-alism, she protested against the moral conservatism and unnatural disdain of the human flesh displayed by powerful politicians and clerics in the first two decades following the establishment of the Irish Free State.

\section{Works Cited:}

Barke, Michael. 2002. “'Inside' and 'outside' writings on Spain: their relationship to Spanish tourism”. Literature and Tourism: Reading and Writing Tourism Texts. Eds. H.C. Andersen and M. Robinson. London: Continuum Books. 80-104.

Beevor, Antony. 1982. The Spanish Civil War. London: Orbis.

Binchy, Maeve. 1986. Introduction to No More Than Human. London: Virago Press. v-xi.

Binchy, Maeve. 1985. Introduction to Never No More. London: Virago Press. xi-xix.

Blaicher, Günter. 1992. Das Deutschlandbild in der Englischen Literatur. Darmstadt: Wissenschaftliche Buchgesellschaft.

Blain, Virginia; Patricia Clements, Isobel Grundy. The Feminist Companion to Literature in English. Women Writers from the Middle Ages to the Present. 1990. London: B. T. Batsford.

Bodenmüller, Thomas. „Der Blick von außen. Spanien in europäischen Reisberichten des 18. Jahrhunderts“. Germanisch-romanische Monatsschrift. 2001; 51(4): 397-418.

Bourke, Angela et al. 2002. Field Day Anthology vol. IV. Cork: Cork University Press. 1037.

Boylan, Henry (ed.). 1998. A Dictionary of Irish Biography. $3^{\text {rd }}$ edition. Dublin: Gill \& Macmillan.

Brady, Anne. 1985. A Biographical Dictionary of Irish Writers. Mullingar: Lilliput Press. 127.

Boada-Montagut, Irene and Robert L. Rothstein. 2002. Women Write Back: Contemporary Irish and Catalan Stories. Dublin: Irish Academic Press.

Bowyer Bell, J.. 1969. “Ireland and the Spanish Civil War, 1936-1939”. Studia Hibernica 9. 137-163.

Brown, Terence. 1991. “The Counter Revival: Provincialism and Censorship 1930-65”. Field Day Anthology III. Derry: Field Day Publications. 89-95.

Brown Terence. 2004. Ireland. A Social and Cultural History. 1922-2002. London: Harper Perennial.

Butler de Foley, María. 1994. "Each Other’s Country. Some Twentieth Century Irish and Spanish Writers”. With Warmest Love. Lectures for Kate O’Brien. Ed. Johan Logan. 15-31.

Carlson, Julia. "Censorship”. 1999. The Blackwell Companion to Modern Irish Culture. Ed. W. J. Cormack. Oxford: Blackwell Publishers. 105.

Carr, Raymond. Modern Spain. 1975-1980. Oxford: Oxford University Press, 1980.

Castle, Barry. 1992. Biographical sketch of Maura Laverty by her daughter Barry Castle in Maura Laverty's The Cottage in the Bog. Dublin: Town House. 6.

Clear, Caitriona. 2001. “I Can Talk About It, Can’t I?”: The Ireland Maura Laverty Desired, 1942-46”. Women’s Studies 30. 819-835.

Commire, Anne (ed.). 2001. Women in World History. A Biographical Encyclopedia vol. 9. Detroit: Yorkin Publications. 206-8.

Dyserinck, Hugo. 1966. "Zum Problem der 'images' und 'mirages' und ihrer Untersuchung im Rahmen der Vergleichenden Literaturwissenschaft.” Arcadia. Zeitschrift für vergleichende Literaturwissenschaft. Berlin: Walter de Gruyer\&Co. 107-120.

Fitz-Simon, Christopher. 1994. The Boys: A Double Biography. Dublin: Gill \& Macmillan. 169-76.

Garrioch, David. 1993. “The Historical Background”. The Spanish Civil War: A Cultural and Historical Reader. Ed. Alun Kenwood. Oxford: Berg. 3-17.

González Molano, Yolanda. 2004. Molly Keane y Kate O’Brien: Nación, Clase y Género. PhD thesis. Universitat Autónoma de Barcelona. 51-52. 
Guerrero, Ana Clara. 1992. "British Travellers in Eighteenth-Century Spain.” In: Studies on Voltaire and the Eighteenth Century 305.1632-35.

Hoehn, Matthew (ed.). 1948. Catholic Authors. Contemporary Biographical Sketches. 1930-1947. St. Mary’s Abbey, Newark.

Howes, Marjorie. 2002. “Public Discourse, Private Reflection, 1916-70”. Field Day Anthology IV. Cork: Cork University Press. 923-930.

Keogh, Dermot. 1994. Twentieth-Century Ireland. Nation and State. Dublin: Gill and Macmillan.

Kime Scott, Bonnie. 1996. "Maura Laverty”. Dictionary of Irish Literature. Ed. Robert Hogan. Westport: Greenwood Press. 683-684.

Laverty, Maura. 1986. No More Than Human. London: Virago Press. (The first edition was published by Longmans, Green and Co Ltd in 1944).

Leerssen, Joseph Theodor. 1991. "Echoes and Images: Reflections upon Foreign Space”. Alterity, Identity, Image: Selves and Others in Society and Scholarship. Eds. J. Th. Leerssen and Raymond Corbey. 128-9.

MacGarry, Fearghal. 1999. Irish Politics and the Spanish Civil War. Cork: Cork University Press.

Madden-Simpson, Janet. 1984. “Woman’s Part. An Anthology of Short Fiction by and about Irishwomen 18901960”. Dublin : Arlen House.

Mahon, Brid. 1998. While Green Grass Grows. Memoirs of a Folklorist. Cork: Mercier Press.

Matthew, H.C.G. and Brian Harrison (eds.). 2004. Dictionary of National Biography vol. 32. Oxford: Oxford University Press. 720-721.

O’Brien, Kate. 1944. Review of No More Than Human by Kate O’Brien. The Spectator, Dec. 22. 584.

O’Faolain, Sean. 1985. Preface to Never No More. London: Virago Press.

Parker, Peter. The Reader's Companion to Twentieth-Century Writers. 1995. London: Fourth Estate Ltd. 417-8.

Preston, Paul. 1996. A Concise History of the Spanish Civil War. London: Fontana Press.

Reynolds, Lorna. 1987. Kate O’Brien. A Literary Portrait. Gerrards Cross: Colin Smythe.

Sheehan, Helena. 1987. Irish Television Drama: A Society and its Stories. Dublin: RTE. 122-130.

Syndram, Karl Ulrich. 1991. “The Aesthetics of Alterity: Literature and the Imagological Approach”. National Identity: Symbol and Representation. Eds. J. Th. Leerssen and M. Spiering. Amsterdam: Rodopi.

Thompson, Mary. 2003. "Maura Laverty”. The Encyclopaedia of Ireland. Dublin: Gill \& Macmillan. 612.

Welch, Robert (ed.). 1996. The Oxford Companion to Irish Literature. Oxford: Oxford University Press. 300.

Zach, Wolfgang. 1987. Literary Interrelations. Ireland, England and the World. Tübingen: Narr. 